\title{
LANGKAH - LANGKAH YANG PERLU DIKETAHUI DAN DITERAPKAN PERAWAT DALAM PROSES KEPERAWATAN
}

\author{
Yudistira Sianipar \\ Yudistirasianipar01@gmail.com
}

\begin{abstract}
ABSTRAK
Perawat adalah suatu profesi yang difokuskan pada perawatan individu, keluarga, dan komunitas dalam mencapai, memelihara, dan menyembuhkan kesehatan yang optimal dan berfungsi. Perawatan adalah sesuatu yang esensial dan sangat penting yang diberikan oleh perawat terhadap individu, keluarga dan masyarakat yang bertujuan untuk menyelesaikan masalah dan memenuhi kebutuhan pasien. Proses keperawatan merupakan metode ilmiah yang digunakan untuk memberikan asuhan keperawatan yang professional, yang merupakan serangkaian tindakan yang secara berurutan dan sistematis melalui pendekatan ilmiah untuk mengatasi dan memecahkan masalah klien, dan memenuhi kebutuhan klien
\end{abstract}

Kata kunci : Proses keperawatan, keperawatan.

\begin{abstract}
Nursing is a profession focused on the individual, family, and community in achieving, healing and healing optimal and functioning health. Care is something that is essential and very important given by nurses to individuals, families and communities that aim to solve problems and meet the needs of patients. The nursing process is a scientific method used to provide professional nursing care, which represents sequential and systematic action through a scientific approach to addressing and solving client problems, and meeting client needs.
\end{abstract}

Keywords : Nursing process, nursing. 


\section{LATAR BELAKANG}

Menurut Deswani (2011) proses keperawatan adalah suatu metode yang sistematis dan terorganisasi dalam pemberian asuhan keperawatan, yang difokuskan pada reaksi dan respon unik individu pada suatu kelompok atau perorangan terhadap gangguan kesehatan yang dialami, baik actual maupun potensial. Standar praktik keperawatan profesional di Indonesia telah dijabarkan oleh Persatuan Perawat Nasional Indonesia (PPNI) pada tahun 2000. Standar tersebut mengacu pada proses keperawatan yang terdiri atas lima tahap, yaitu pengkajian, diagnosis, perencanaan, implementasi, dan evaluasi.

$\begin{array}{clc} & \text { Pada } & \text { mulanya, seorang } \\ \text { dalam } & \text { melaksanakan } & \text { asuhan }\end{array}$
keperawatannya hanya sebagai rutinitas kerja saja tanpa berpedoman pada dasardasar ilmiah tindakan keperawatan. Akan tetapi pada masa sekarang perawat dihadapkan dengan pemberian asuhan keperawatan yang berkualitas dan perawat profesional sebagai penyedia perawatan kesehatan yang terdidik dengan baik. Keperawatan menghadapi dua tantangan dalam memberikan perawatan yang berkualitas dalam sistem perawatan kesehatan yang berubah dengan cepat.
Pertama, para perawat saat ini merawat klien-klien dengan masalah kesehatan yang lebih kompleks dari pada sebelumnya. Kedua, para perawat sebagai individu mempunyai ciri dan karakteristik yang berbeda serta kemampuan dasar yang berbeda-beda.

Proses keperawatan adalah kerangka yang memungkinkan keperawatan dapat mengidentifikasi keunikan dalam masyarakat serta dapat mengidentifikasi respon manusia terhadap masalah kesehatannya yang meliputi perubahan kesehatan, kesejahteraan, dan gaya hidup klien. Rencana keperawatan harus mencakup segala aspek kebutuhan pasien seperti fisik, emosional, sosial, spiritual dan budaya menjadi tuntutan untuk membuat kerangka yang sistematis.

$$
\text { Langkah - langkah proses }
$$
keperawatan meliputi pengkajian, diagnosis keperawatan, perencanaan, intervensi, dan evaluasi. Kelima langkah ini digunakan secara siklis dan berulang kali selama perawatan pasien. Urutan harus diikuti dari awal hingga akhir untuk memastikan bahwa kebutuhan pasien terpenuhi. Faktor penting dalam proses keperawatan yaitu seorang perawat sseorang perawat memilki tanggung jawab bukan hanya sebagai pemberi 
perawatan kepada pasien akan tetapi memilki tanggung jawab besar dalam melaksanakan tugas sebagai pemberi asuhan keperawatan yang baik kepada pasiennya dengan memperhatikan segala aspek kondisi pasien yang ada. Dengan begitu tujuan asuhan keperawatan dapat tercapai.

\section{METODE}

Metode yang digunakan disini adalah Literature review yang melakukan analisa dan kajian bebas terhadap artikel, buku, koran, majalah, jurnal print maupun jurnal online, Thesis, disertasi, text book, maupun ebook yang sesuai dan berfokus pada pengetahuan dalam penggunaan apd (alat pelindung diri) yang harus dimiliki oleh perawat guna untuk menghindari berbagai penyakit serta kecelakaan dalam menjalankan tugasnya. Adapun artikel yang digunakan pada literature review ini adalah artikel yang didapatkan dengan memuat 3 database Pubmed, Geogle Scholar dan Science Direct dengan memasukkan kata kunci "Proses Keperawatan", “keperawatan". Artikel yang digunakan 10 referensi dengan tahun paling tua tahun 2012.

\section{HASIL}

Berdasarkan hasil pencarian literature review dengan menganalis buku, majalah, koran, jurnal print maupun jurnal online, Thesis, disertasi, didapatkan bahwa proses keperawatan adalah suatu cara atau metode yang sistematis dalam memberikan asuhan keperawatan yang dilakukan oleh perawat dan bekerjasama dengan pasien (individu, keluarga, masyarakat) yang bertujuan untuk mengidentifikasi masalah keperawatan dengan melakukan pengkajian, menentukan, diagnosa, merencanakan tindakan yang akan dilakukan, melaksanakan tindakan serta mengevaluasi hasil asuhan keperawatan yang telah diberikan dengan berfokus pada pasien, berorientasi pada tujuan yang telah ditetapkan bersama (Budiono, 2016).

Perawat diharuskan memahami setiap dari langkah-langkah proses keperawatan dalam menentukan tindakan asuhan keperawatan dan mengambil keputusan dengan aman dan tepat. Jikalau dari setiap langkah dari proses keperawatan tidak dilaksanakan dengan baik proses keperawatan tidak aka terjadi dan berdampak kepada pasien hasilnya tindakan keperawatan tidak sesuai dengan yang direncanakan.

$$
\text { Langkah - langkah proses }
$$
keperawatan meliputi pengkajian, diagnosis keperawatan, perencanaan, intervensi, dan evaluasi. Kelima langkah ini digunakan secara siklis dan berulang kali selama 
perawatan pasien. Urutan harus diikuti dari awal hingga akhir untuk memastikan bahwa kebutuhan pasien terpenuhi. Faktor penting dalam proses keperawatan yaitu seorang perawat sseorang perawat memilki tanggung jawab bukan hanya sebagai pemberi perawatan kepada pasien akan tetapi memilki tanggung jawab besar dalam melaksanakan tugas sebagai pemberi asuhan keperawatan yang baik kepada pasiennya dengan memperhatikan segala aspek kondisi pasien yang ada.

Dengan adanya proses keperawatan seorang perawat dapat dengan mudah memecahkan permasalahan kesehatan, mengetahui bagaimana respon klien terhadap masalah kesehatannya, dapat melakukan diagnosis keperawatan, melakukan perencanaan untuk mendapatkan solusi dari masalah kesehatan klien, melakukan intervensi sesuai dengan yang telah direncanakan serta sesuai dalam standar asuhan keperawatan, dan melakukan evaluasi terhadap pemecahan masalah yang telah dilakukan.

\section{PEMBAHASAN}

Perawat adalah kelompok profesional kesehatan terbesar di semua negara. Untuk mencapai mutu pelayanan kesehatan, asuhan keperawatan merupakan kunci dan untuk memenuhi tuntutan penerapan proses keperawatan yang memiliki peran signifikan, tetapi dalam prakteknya penerapan proses keperawatan tidak berkembang dengan baik. Perawat dengan tingkat keahlian yang lebih tinggi cenderung tidak menggunakan proses keperawatan sebagai sistem atau paket perawatan yang lengkap, lebih mengandalkan intuisi dan atau penilaian klinis berpengalaman yang mungkin juga memperburuk masalah. Sejalan dengan perkembangan ilmu pengetahuan dan teknologi, berkembang pula ilmu keperawatan.

Perkembangan ini juga diirigi dengan pengakuan perawat sebagai suatu profesi. Dari pengakuan sebagai profesi yang mandiri ini, perawat menggunakan pendekatan proses keperawatan. proses keperawatan adalah serangkaian tindakan yang sistematis berurutan berkelanjutan atau berkesinambungan dimulai dari pengumpulan data, menentukan masalah keperawatan, menyusun desain rencana tindakan keperawatan, melaksanakan tindakan dan atau menugaskan orang lain untuk melaksanakan tindakan dan mengevaluasi keberhasilan.

Proses keperawatan ini diperkenalkan pada tahun 1950-an sebagai proses yang terdiri atas tiga tahap : 
Pengkajian, perencanaan dan evaluasi yang didasarkan pada metode ilmiah pengamatan, pengukuran, pengumpulan data dan penganalisaan temuan.

Kajian selama bertahun-tahun, penggunaan dan perbaikan telah mengarahkan perawat pada pengembangan proses keperawatan menjadi lima langkah yang konkret (pengkajian, identifikasi masalah, perencanaan, implementasi dan evaluasi) yang memberikan metode efisien tentang pengorganisasian proses berfikir untuk pembuatan keputusan klinis.

Potter \& Perry (2005) menjelaskan tujuan dari proses keperawatan adalah mengidentifikasi kebutuhan perawatan kesehatan klien, menentukan prioritas, memberikan intervensi keperawatan yang dirancang untuk memenuhi kebutuhan klien, dan mengevaluasi keefektifan asuhan keperawatan dalam mencapai hasil dan tujuan klien yang diharapkan. Tujuan umum dari proses keperawatan adalah sebuah sistem. Apapun yang tergolong sistem, tujuannya adalah peningkatan kualitas. Sistem pada proses keperawatan akan menciptakan pelayanan asuhan keperawatan yang berkualitas dengan indikator tertasinya semua masalah yang terkait dengan kebutuhan dasar klien.
Adapun manfaat dari proses keperawatan bagi seorang perawat adalah, yang pertama Lebih mempunyai rasa pecaya diri dalam melaksanakan asuhan keperawatan, karena semua perencanaan disusun dengan baik berdasarkan pada diagnosis keperawatan yang ditunjang oleh data yang tepat dan akurat. Kedua dengan proses keperawatan akan memberikan peningkatan kualitas asuhan keperawatan.Ketiga proses keperawatan yang diterapkan akan membantu pengembangan profesionalisme seorang perawat.Dan yang terakhir proses keperawatan yang terdokumentasi dengan baik akan memudahkan dalam memberikan asuhan keperawatan.

Sementara untuk klien pentingnya proses keperawatan adalah klien akan ikut berpasrtisipasi dalam menetukan perencanaan keperawatan, dan meningkatkan kerjasama klien dalam pelaksanaan tindakan keperawatan, proses keperawatan menjamin klien untuk mendapatkan asuhan keperawatan yang berkesinambungan, mencegah terjadinya duplikasi tindakan dan kekurangan tindakan, serta klien mendapatkan kualitas pelayanan asuhan keperawatan yang prima.

Bagi fasilitas kesehatan juga mendapat kepuasan klien, klien yang merasa 
puas atas pelayanan yang didapatkan akan meceritakan kepada orang lain sehingga orang lain tahu bahwa fasilitas kesehatan tersebut memberikan pelayanan kesehatan yang sangat baik, dengan menambahnya jumlah klien maka akan meningkatkan pendapatan fasilitas kesehatan.

Dalam proses keperawatan ini sendiri terdapat tahapan-tahapan yaitu pengkajian, diagnosis, perencanaan, implementassi dan evaluasi.Semua komponen ini terpisah, tapi saling bergantung, saling berhubungan untuk mencapai tujuan yang telah ditentukan, setiap langkah dapat dipengaruhi apabila situasi berubah karena proses keperawatan diterapkan dengan melihat kebutuhan keperawtan klien yang unik.

\section{Pengkajian}

Pengkajian adalah tahap awal dari proses keperawatan dan merupakan proses yang sistematis dalam pengumpulan data dari berbagai sumber data untuk mengidentifikasi status kesehatan pasien. Tujuan pengkajian adalah :

a) Untuk memperoleh informasi tentang keadaan kesehatan pasien.

b) Untuk menentukan masalah keperawatan dan kesehatan pasien.

c) Untuk menilai keadaan kesehatan pasien. d) Untuk membuat keputusan yang tepat

dalam menentukan langkah-langkah berikutnya. Dalam melakukan pengkajian terdapat 2 jenis data yang dikumpulkan yaitu data subjektif dan data objektif.

\section{Diagnosa}

Diagnosa keperawatan adalah langkah kedua dari proses keperawatan yang menggambarkan penilaian klinis tentang respon individu, keluarga, kelompok maupun masyarakat terhadap permasalahan kesehatan baik aktual maupun potensial. Dimana perawat mempunyai lisensi dan kompetensi untuk mengtasinya (Sumijatun, 2010).

\section{Perencanaan keperawatan}

Perencanaan keperawatan merupakan langkah ketiga dari proses keperawatan. Perencanaan keperawatan adalah suatu proses perencanaan tindakan yang akan dilakukan, bagaimana dilakukan, kapan dilakukan, siapa yang melakukan dari semua tindakan keperawatan.

4. Implementasi keperawatan 
Implementasi keperawatan

adalah pengelolaan dan pelaksanaan tindakan keperawatan yang telah direncanakan sebelumnya.

5. Evaluasi keperawatan

Evaluasi keperawatan adalah kegiatan akhir yang harus dilakukan untuk menilai respon pasien apakah rencana keperawatan efektif dan bagaimana rencana keperawatan dilanjutkan, merevisi rencana atau menghentikan rencana keperawatan. Evaluasi selalu berkaitan dengan tujuan jika dalam evaluasi yang dilakukan ternyata tujuan tidak tercapai maka perlu mencari penyebabnya. Beberapa faktor yang dapat menyebabkannya adalah tujuan yang tidak realistis, tindakan keperawatan yang tidak tepat dan faktor lingkungan yang tidak dapat diatasi.Secara umum, evaluasi ditujuankan untuk:

1. Melihat dan menilai kemampuan klien dalam mencapai tujuan.

2. Mengkaji penyebab jika tujuan asuhan keperawatan belum tercapai (Asmadi,2008)

Proses keperawtan mempunyai sifat-sifat yaitu:

a. Terbuka dan fleksibel
Proses keperawatan menganut sistem terbuka karena jika sewaktu-waktu terjadi respon klien maka akan memberikan perubahan terhadap diagnosis, rencana dan tindakan yang diberikan oleh perawat. Fleksibel karena setiap rencana yang telah disusun tidak harus semua dilaksanakan seluruhnya tetapi harus elihat perubahan dan perkembangan kondisi klien

b. Dilakukan pendekatan individual Untuk menghadapi klien, ada banyak hal yang bersifat individual dan merupakan privasi klien. Jadi tidak semua perawat dapat dipercaya oleh klien, atau tidak semua data yang didapatkan byang berhubungan dengan masalah keperawatan akan disampaikan oleh klien kepada perawat. Sehingga pada situasi yang seperti inilah pendekatan individual dilakukan agar mampu membina hubungan saling percaya dengan klien.

c. Penanganan masalah yang terencana

Setelah permasalahan keperawatan ditemukan dengan 
dilengkapi oleh data yang

merupakan karakteristik dari

masalah, maka perawat

melakukan perencanaan yang

berlandaskan pada ilmu

keperawatan dan profesinalisme

sebagai seorang perawat.

d. Mempunyai arah dan tujuan

Perencanaan yang telah disusun

mempunyai arah dan tujuan yang

akan dicapai dalam batas waktu tertentu.

e. Merupakan siklus yang saling berhubungan Setiap tahap dalam proses keperawatan saling berhubungan dan tidak dapat dipisahpisahkan.

f. Terdapat validasi data dan pembuktian masalah Selalu ada pengkajian ulang terhadap data yang didapatkan.

g. Menekankan terjadinya umpan balik dan pengkajian ulang yang komprehensif Pada saat perawat melaksanakan pengkajian sampai dengan evaluasi keperawatan, maka akan ada perubahan respon yang merupaka umpan balik untuk perawat dan akan menjadi data yang baru.

\section{PENUTUP}

Proses keperawatan terdiri dari lima tahap, yaitu : pengkajian, diagnosis, perencanaan, implementasi, dan evaluasi. Setiap tahap dari proses keperawatan saling terkait satu sama lain dan ketergantungan satu sama lain. Jikalau kita ingin melakukan tahap tahap proses keperawatan maka perawat memerlukan keterampilan dan pengetahuan agar masalah kesehatan klien dapat diselesaikan dan dapat mengambil keputusan dengan tepat dan benar.

Untuk menjadi perawat profesional paling penting harus dapat menguasai langkah-langkah dari setiap proses keperawatan dengan tergolong kategori baik. Tingkat pengetahuan yang tergolong baik dalam hal ini sejalan dengan penerapan langkah-langkah dalam proses keperawatan yang baik.

\section{DAFTAR PUSTAKA}

AL-Fattah, M. N. (2019). Assessments of The Application Of Nursing Process In Surgical Wards. Mosul Journal of Nursing , 7 (1), 50-59.

Budiono \& Pertami, S. B. (2016). Konsep Dasar Keperawatan. Jakarta: Bumi Medika 
Dermawan, D. (2012). Proses keperawatan penerapan konsep dan kerangka kerja (1st De). Yogyakarta : Gosyen Publishing

Ead, H. (2019). Application Of The Nursing Process In A Complex Health Care Environment (article)

Hagos, F., Alemseged, F., Balcha, F., Berhe, S., and Aregay, A. (2014). Application of Nursing Process and Its Affecting Factors among Nurses Working in Mekelle Zone Hospitals. Northern Ethiopia.

Hindawi Publishing Corporation Nursing Research and Practice

Indriatie. (2013). Berfikir Kritis dalam

Proses Keperawatan. Jurnal

Keperawatan. 6(2)

INC2019 12th International Nursing Conference. 2019.10455 - 455 (1 pages)UCI(KEPA) : I410-ECN0101-2019-512-001224337

Rivas, F. J. P., Martín-Iglesias, S., Cerro, J. L. P. D., Arenas, C. M., López, M. G., and Lagos M. B. (2016). Effectiveness of Nursing Process Use in Primary Care. International Journal of Nursing Knowledge. 27(1)
Rohmah, N dan Walid, S. (2019). Proses Keperawatan Berbasis KKNI. Malang: Edulitera

Stonehouse, DP. (2017). Understanding The Nursing Process. University Of Salford Manchester (Article).

Simamora, R. H. (2019). Development of Guidelines for Applying appropriate Patient Identification to Achieve Patient Safety Goal

Simamora. R. H. (2008)The correlation of ward chief's giving direction and command and the performance of on-duty nurses at Jember $\mathrm{dr}$. Subandi general hospital inpatient wards.jurnalAdministrasidanKebij akanKesehatan, (https://fkm.unair.a c.id/jurnal-administr)

Younas, A. (2017). The Nursing Process and Patient Teaching. Wolters Kluwer Health article.15(6). 13-16 
